\title{
Association of 'Candidatus Phytoplasma aurantifolia' with Cosmos bipinnatus phyllody disease in Iran
}

\author{
Mehrnoosh Nikooei ${ }^{1 *}$, Chamran Hemmati², Abdoolnabi Bagheri ${ }^{3}$ \\ ${ }^{1}$ Department of Agriculture, Faculty of Agriculture and Natural Resources, University of Hormozgan, Bandar Abbas, Iran \\ ${ }^{2}$ Young Researcher and Elite Clubs, Bandar Abbas Branch, Islamic Azad University, Bandar Abbas, Iran \\ ${ }^{3}$ Plant Protection Research Department, Hormozgan Agricultural and Natural Resources Research and Education Center, \\ Agricultural Research Education and Extension Organization (AREEO), Bandar Abbas, Iran
}

Vol. 57, No. 3: 314-317, 2017

DOI: 10.1515/jppr-2017-0037

Received: May 11, 2017

Accepted: August 31, 2017

*Corresponding address: Mehr.nikooei@gmail.com

\begin{abstract}
In 2017 growing season numerous examinations of Cosmos bipinnatus in Hormozgan province, Iran revealed the disease symptoms similar to those associated with phytoplasmas. Phytoplasmas were detected from all symptomatic plants by the specific polymerase chain reaction (PCR) utilizing phytoplasma universal primer pairs. Amplification, sequencing and BLAST analysis of $16 \mathrm{~S}$ rDNA fragment ( ca. $1.2 \mathrm{~kb}$ ) demonstrated that $C$. bipinnatus plants were infected by a phytoplasma belonging to the 16SrII group. This is the first report of association of a 'Candidatus Phytoplasma aurantifolia'-related strain with C. bipinnatus phyllody in Iran.
\end{abstract}

Key words: 'Candidatus Phytoplasma aurantifolia', Cosmos bipinnatus, Mexican aster, phyllody, phytoplasma
Phytoplasmas, cell wall-less phytopathogenic bacteria, belonging to the Mollicutes class (Firrao et al. 2005) are associated with numerous devastating diseases in ornamental plants worldwide. Epidemics of these diseases have compelled withdrawal of many ornamental plant varieties from cultivation. Symptoms of general yellowing and stunting of plants, proliferation of shoots, phyllody, virescence and reduced size of flowers as well as reddening of leaves are commonly observed on ornamental plants and their occurrence often results in high economic losses (Chaturvedi et al. 2010).

Cosmos bipinnatus (Asteraceae, Coreopsidae) commonly called the garden cosmos or Mexican aster is a medium-size flowering herbaceous plant native to Mexico. The species and its varieties are popular as an ornamental plant in temperate climate gardens (Paniagua-Ibanez et al. 2015). Cosmos bipinnatus is an economically important ornamental plant species used in residential and commercial landscapes in Hormozgan province.

In February 2017, typical symptoms of phytoplasma diseases including phyllody, virescence, little leaf and stunting (Fig. 1) were observed in several C. bipinnatus plants in urban green space of Bandar Abbas, Hormozgan province, Iran.

Five samples of both symptomatic and two samples of asymptomatic C. bipinnatus were collected from urban green space of Bandar Abbas (N2711'40"; E56 $\left.{ }^{\circ} 9^{\prime} 58^{\prime \prime}\right)$, Hormozgan province, Iran. To verify the possibility of a phytoplasma association with the symptoms, a total DNA was extracted from all symptomatic and asymptomatic plants using cetyltrimethylammonium bromide (CTAB) extraction procedure described by Doyle and Doyle (1990). The samples were examined for phytoplasma DNA by direct-PCR using the phytoplasma universal primer pair P1/P7 (Deng and Hiruki 1991; Schneider et al. 1995) and nestedPCR using primers P1/P7 (first round) followed by R16F2n/R16R2 (Gundersen and Lee 1996). A nestedPCR product of approximately $1.2 \mathrm{~kb}$ was directly sequenced. The PCR was performed in $20 \mu \mathrm{l}$ of reaction mixture containing $10 \mu \mathrm{l}$ PCR Master Mix (Amplicon), $1 \mu \mathrm{l}$ of each primer $(10 \mu \mathrm{M}), 2 \mu \mathrm{l}$ of template DNA and $6 \mu$ sterile distilled water. The thermocycling program 


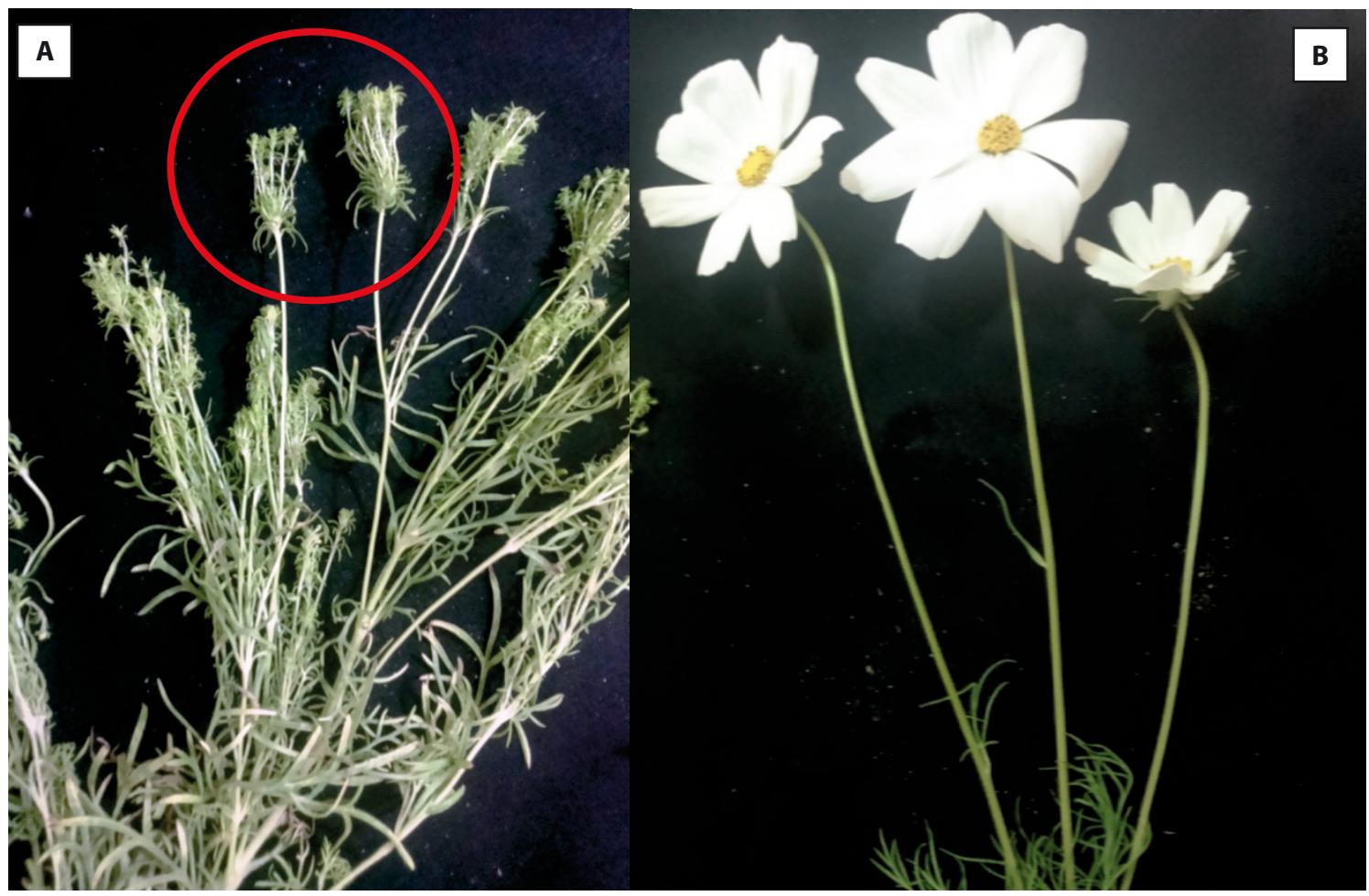

Fig. 1. Symptoms of little leaf, virescence and phyllody in Cosmos bipinnatus (shown in red circle): A - plant with visible symptoms, B - healthy plant

consisted of an initial denaturation step at $95^{\circ} \mathrm{C}$ for $3 \mathrm{~min}$, followed by 35 cycles of denaturation at $94^{\circ} \mathrm{C}$ for $30 \mathrm{~s}$, annealing at $55^{\circ} \mathrm{C}$ for $40 \mathrm{~s}$ and extension at $72^{\circ} \mathrm{C}$ for $90 \mathrm{~s}$, with a final extension step at $72^{\circ} \mathrm{C}$ for $10 \mathrm{~min}$. The $\mathrm{P} 1 / \mathrm{P} 7$ primed PCR product was diluted at $1: 10 \mathrm{ra}-$ tio in sterile water and $2 \mu \mathrm{l}$ was used in nested-PCR as a template. The nested-PCR cycles were the same as for the first round PCR.

Sequence used in phylogenetic analysis was checked and aligned using software DNAstar and ClustalX. Phylogenetic analysis was conducted by neighbor joining (NJ) methods using MEGA 6.0. Software (Tamura et al. 2013). The sequences of $16 \mathrm{~S}$ rDNA of phytoplasma used in comprehensive phylogenetic analysis were downloaded from GenBank (the accession numbers are given in brackets in Figure 2).

Amplicons of $c a .1 .8$ and $1.25 \mathrm{~kb}$ were amplified from five symptomatic plants with direct and nestedPCR, respectively, but not from symptomless plants or sterile distilled water as negative controls. A positive nested-PCR product was directly sequenced, edited and deposited in GenBank under MF186858 accession number.

Blast analysis of the $1.25 \mathrm{~kb}$ of ribosomal RNA gene revealed that the phytoplasma associated with $C$. bipinnatus phyllody (CbP) shared 99\% identity with strains of group 16SrII (peanut witches' broom group), including alfalfa witches' broom (KT6341420), 'Candidatus Phytoplasma aurantifolia' (KX013260), tomato big bud phytoplasma (KP027532) and faba bean phyllody phytoplasma (KP869129). Phylogenetic analysis based on the 16S rRNA gene sequence of the phytoplasma associated with $C$. bipinnatus and other phytoplasmas exhibited that the $C$. bipinnatus phyllody phytoplasma is a member of the $16 \mathrm{SrII}$ phytoplasma clade (Fig. 2). This result was further confirmed by the analysis using $i$ PhyClassifier online tool (Zhao et al. 2009), where it was determined that $C$. bipinnatus phytoplasma related to 16 SrII group, subgroup D.

In Iran, group16SrII phytoplasmas have been identified in association with many diseases such as witches' broom disease of lime (WBDL), cabbage yellow, clover little leaf, alfalfa witches' broom, tomato witches' broom, sunflower phyllody, cucumber and squash phyllody, carrot witches' broom, parsley witches' broom, pomegranate little leaf, bell pepper big bud and elegant zinnia phyllody (Hemmati and Nikooei 2017). Association between phytoplasmas and C. bipinnatus has been previously reported by Wang and Hiruki (2001) and Chen et al. (2011) who showed the C. bipinnatus, infected by 'Candidatus Phytoplamsa asteris'-related strains in Canada and Taiwan, respectively. In addition, Rojas-Martinez et al. (2003) revealed that the phytoplasma associated with cosmos disease in Mexico belongs to subgroup B from the aster yellows phytoplasma group $16 \mathrm{SrI}$. Since symptoms affect the architecture and aesthetics of private and public gardens and parks, phytoplasmas infected ornamentals 


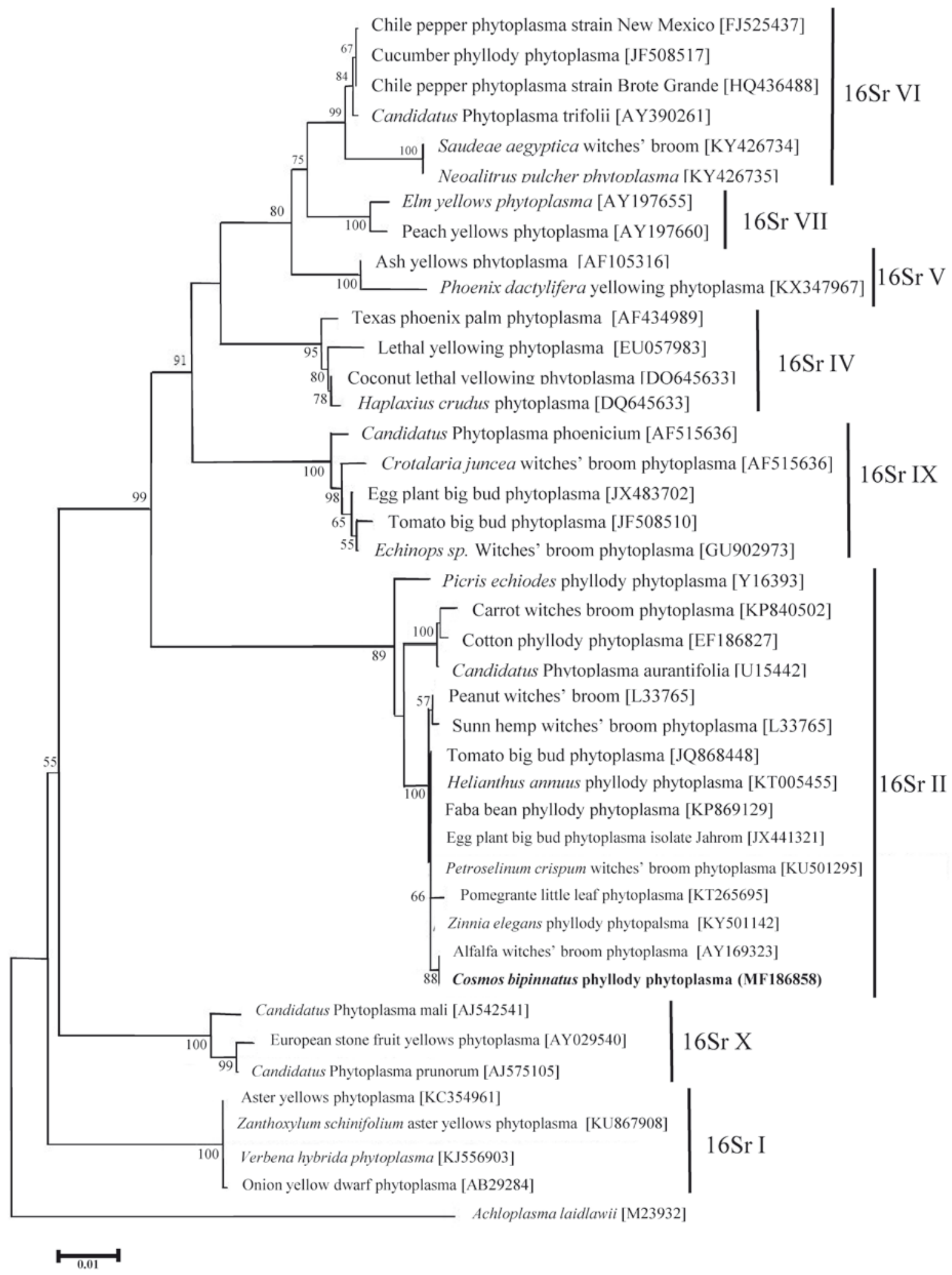

Fig 2. Phylogenetic tree inferred from partial $16 \mathrm{~S}$ rDNA gene sequence from Cosmos bipinnatus phyllody phytoplasma isolate (marked by bold face type) and selected phytoplasma sequences. GenBank accession numbers are shown in brackets, and 16Sr groups are annotated to the right. Acholeplasma laidlawii was used as outgroup to root the tree. The tree was constructed by the neighbor-joining method using MEGA 6 software. Bootstrap values are shown at nodes with greater than 50\% support

are of a global economic importance. In addition, phytoplasma-infected C. bipinnatus plants may pose an epimiological threat to the other ornamentals or nearby plant species. This is the first report on detection of a 'Candidatus Phytoplasma aurantifolia'-related strain (16SrII group) affecting C. bipinnatus in Iran. Further studies will be required to identify the insect vector of the phytoplasma. 


\section{References}

Chaturvedi Y., Rao G.P., Tewari A.K., Duduk B., Bertaccini A. 2010. Phytoplasma on ornamentals: detection, diversity and management. Acta Phytopathologica et Entomologica Hungarica 45 (1): 31-69. DOI: https://doi.org/10.1556/ aphyt.45.2010.1.3

Chen W., Huang Y., Tsai M., Lin C. 2011. Detection and identification of a new associated with periwinkle leaf yellowing disease in Taiwan. Australas Plant Pathology 40 (5): 476-483. DOI: https://doi.org/10.1007/s13313-011 $-0062-\mathrm{x}$

Deng S., Hiruki C. 1991. Amplification of 16Sr RNA genes from culturable and non-culturable mollicutes. Journal of Microbiological Methods 14 (1): 53-61. DOI: https://doi. org/10.1016/0167-7012(91)90007-d

Doyle J.J., Doyle J.L. 1990. A rapid total DNA preparation procedure for fresh plant tissue. Focus 12: 3-15.

Firrao G., Gibb K., Streten C. 2005. Short taxonomic guide to the genus 'Candidatus phytoplasma'. Journal of Plant $\mathrm{Pa}$ thology 87 (4): 249-263.

Gundersen D.E., Lee I.M. 1966. Ultrasensitive detection of phytoplasma by nested-PCR assays using two universal primer sets. Phytopathologia Mediterranea 35 (3): 144-151.

Hemmati C., Nikooei M. 2017. Molecular characterization of a Candidatus Phytoplasma aurantifolia-related strain associated with Zinnia elegans phyllody in Iran. Australasian Plant
Disease Notes 12 (1): 1-4. DOI: https://doi.org/10.1007/ s13314-017-0234-9

Rojas-Martinez R.I., Zavaleta-Mejia E., Martinez-Soriano J.P., Lee I.M. 2003. Identification of the phytoplasma associated with cosmos (Cosmos bipinnatus cav.) phyllody and classification by RFLP analysis of $16 \mathrm{~S}$ rDNA. Revista Mexicana de Fitopathologia 21 (1): 83-86.

Schneider B., Seemuller E., Smart C.D., Kirkpatrick B.C. 1995. Phylogenetic classification of plant pathogenic mycoplasmalike organism or phytoplasma. p. 369-380. In: "Molecular and Diagnostic Procedures in Mycoplasmology" (S. Razin, J.G. Tully, eds.) Academic Press, New York, USA.

Tamura K., Stecher G., Peterson D., Filipski A., Kumar S. 2013. MEGA6: Molecular Evolutionary Genetics Analysis Version 6.0. Molecular Biology and Evolution 30 (12): 2725-2729. DOI: https://doi.org/10.1093/molbev/mst197

Wang K., Hiruki C. 2001. Use of heteroduplex mobility assay for identification and differentiation of phytoplasmas in the aster yellows group and the clover proliferation group. Phytopathology 91 (6): 546-552. DOI: https://doi.org/10.1094/ phyto.2001.91.6.546

Zhao Y., Wei W., Lee I.M., Shao J., Suo X.B., Davis R.E. 2009. Construction of an interactive online phytoplasma classification tool, iPhyClassifier, and its application in analysis of the peach X-disease phytoplasma group (16SrIII). International Journal of Systematic and Evolutionary Microbiology 59 (10): 2582-2593. DOI: https://doi.org/10.1099/ijs.0.010249-0 